in vivo $33: 1059-1066$ (2019)

doi:10.21873/invivo.11574

Review

\title{
Incisional Hernias Post Liver Transplantation: Current Evidence of Epidemiology, Risk Factors and Laparoscopic Versus Open Repair. A Review of the Literature
}

\author{
NIKOLAOS GARMPIS ${ }^{1,2}$, ELEFTHERIOS SPARTALIS ${ }^{2,3}$, DIMITRIOS SCHIZAS ${ }^{2,4}$, \\ DIMITRIOS PATSOURAS ${ }^{2,3}$, CHRISTOS DAMASKOS $^{1}$, MICHAEL SPARTALIS $^{3}$, \\ ANNA GARMPI $^{5}$, NIKOLAOS I. NIKITEAS ${ }^{2,3}$ and DIMITRIOS DIMITROULIS ${ }^{1,2}$ \\ ${ }^{1}$ Second Department of Propedeutic Surgery, Laiko General Hospital, Medical School, \\ National and Kapodistrian University of Athens, Athens, Greece; \\ ${ }^{2}$ Hellenic Minimally Invasive and Robotic Surgery (MIRS) Study Group, Athens, Greece; \\ ${ }^{3}$ Laboratory of Experimental Surgery and Surgical Research, \\ National and Kapodistrian University of Athens Medical School, Athens, Greece; \\ ${ }^{4}$ First Department of Surgery, Laiko General Hospital, Medical School, \\ National and Kapodistrian University of Athens, Athens, Greece; \\ ${ }^{5}$ Internal Medicine Department, Laiko General Hospital, Medical School, \\ National and Kapodistrian University of Athens, Athens, Greece
}

\begin{abstract}
Background/Aim: The occurrence of an incisional hernia after liver transplantation consists of a potential complication that may seriously affect the postoperative course and the quality of patient's life in general. The purpose of this study was to report the current epidemiological data, analyze the risk factors, evaluate the role of laparoscopic repair in this condition, and present the technical difficulties in the management of this special patient group. Materials and Methods: A literature search was performed through PubMed. Our criteria included all studies published from March 1982 to February 2019 in English, regarding incisional posttransplant hernias and open or laparoscopic repair. Finally, we collected 19 relevant studies. Results: Incisional hernia may occur independently of the type of abdominal incision. Risk factors are both patient- and technique-related.
\end{abstract}

This article is freely accessible online.

Correspondence to: Dr. Nikolaos Garmpis, MD, M.Sc.(S), Ph.D.(C), Second Department of Propedeutic Surgery, Laiko General Hospital, National and Kapodistrian University of Athens, Medical School, 17 Agiou Thoma Street, Athens, 11527, Greece. Tel: +30 6976291403, e-mail: nikosg22@ hotmail.com

Key Words: Incisional, hernia, abdominal, liver, transplantation, review.
Conclusion: Well-organized randomized controlled studies are needed, in order to estimate the best treatment strategy for these patients.

An incisional hernia may complicate any abdominal incision, regardless of the type of incision (Figure 1A and B). However, median abdominal incisions have been documented to be more prone to incisional hernia formation, compared with other abdominal incisions $(1,2)$. According to a systematic review, median incisions carry a significantly higher risk of herniation compared to transversal [relative risk (RR) $1.77,95 \% \mathrm{CI}=1.09-2.87]$, and paramedian incisions ( $R R=3.41,95 \% C I=1.02-11.45)$, respectively (3).

Risk factors predisposing to incisional hernia are both patient- and technique-related. Patient-related factors that increase such a risk include obesity, smoking, malnutrition, connective tissue disorders, preoperative chemo-radiation and immunosuppressive therapy $(4,5)$. As for techniquerelated factors, excess wound tension, suturing material failure, poor surgical technique, as well as the need for emergency surgery, are amongst the most important factors predisposing to the development of incisional hernia.

The development of an incisional hernia following liver transplantation (LT) comprises a potential complication that may seriously affect the postoperative course and the quality of patient's life. The purpose of the present study was to investigate the current epidemiological data, analyse the risk 

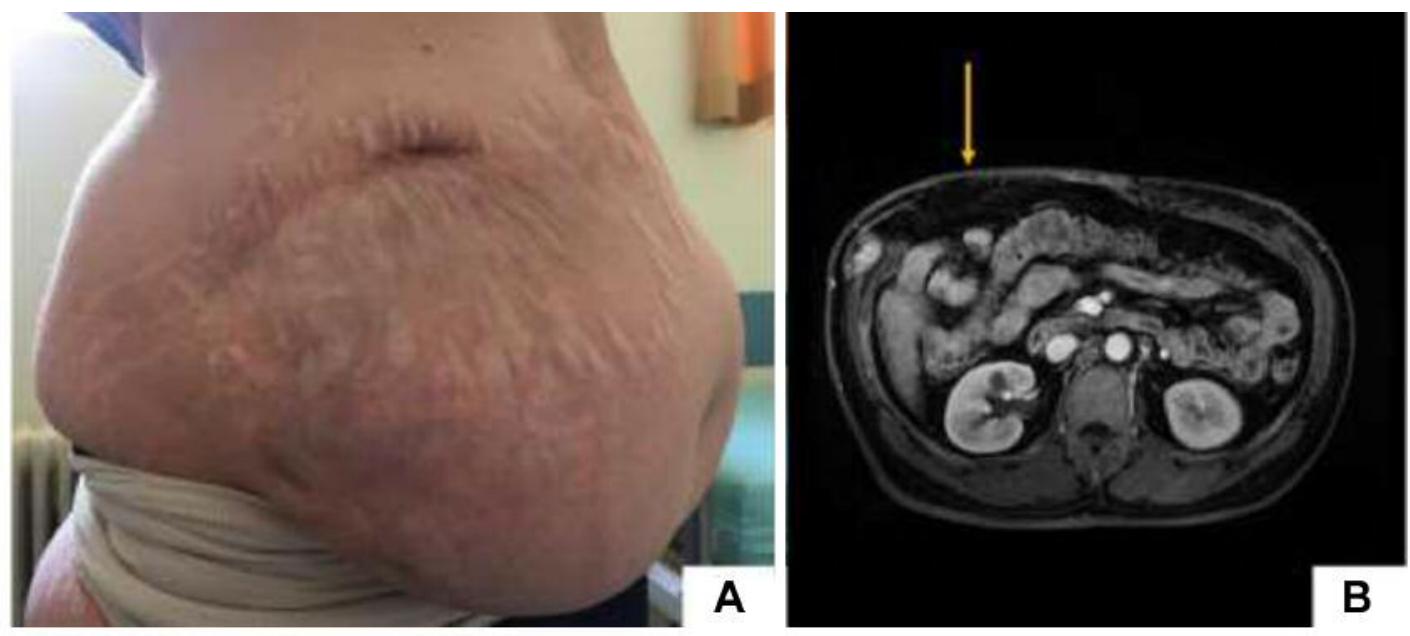

Figure 1. A: Incisional hernia in a 35-year-old female patient, 3 years after orthotopic liver transplantation; B: Magnetic resonance imaging (MRI) illustrating right abdominal wall gap.

factors predisposing to the development of incisional hernia following LT, and evaluate the feasibility and safety of laparoscopic techniques in the surgical management of these technically demanding cases.

\section{Materials and Methods}

A detailed search in PubMed and Medline, using the algorithm ([Liver] AND [transplantation] AND [incisional] AND [hernia]) revealed 94 studies. After an initial review of these studies, papers written in languages other than English or missing full-text, were excluded from the analysis. Finally, 19 studies matched our criteria, and a review of these reports was conducted (Figure 2, Table I).

\section{Results}

Epidemiology - risk factors. The lifetime risk for incisional hernia formation in liver transplant recipients ranges from $1.7 \%$ (6) to $43 \%$ (7), even though lower rates have been reported $(6,8-10)$.

In 2002, a group of German investigators studied 290 liver transplant patients for 10 years and reported a $17 \%$ rate of incisional hernia formation (11). The same group concluded that acute rejection (with steroid treatment), post-surgery thrombocytopenia and Mercedes type incision were risk factors.

The type of abdominal incision is an important risk factor contributing to the development of incisional hernia. A large study including almost 1000 patients, with an exclusive use of a Mercedes incision, reported an incisional hernia rate below 5\% (12). In the study published by Gastaca et al., with more than 600 patients having been operated with a bilateral subcostal incision, the incisional hernia rate was reported to be $1.7 \%$, much lower than the rate associated with the Mercedes incision (6). Another study published by Montalti et al., has reported an incisional hernia rate of $32.4 \%$, and mTOR inhibitor rapamycin (Sirolimus), male sex, high BMI, and MELD score $>22$ were identified as risk factors (9). Kahn et al. has also reported on a high hernia rate exceeding $23 \%$, and considered Sirolimus (prescribed in almost $20 \%$ of transplanted patients suffering of hernias), along with end stage cirrhosis as major risk factors (13).

Risk factors for incisional hernias following LT are numerous. In detail, male sex, abdominal re-interventions, living-donor liver transplantation, postoperative respiratory complications, immunosuppressive therapy with the use of steroids, prolonged stay in intensive care unit, acute rejection, severe post-transplantation ascites, viral hepatitis, obesity $\left(\right.$ BMI $\left.>25 \mathrm{~kg} / \mathrm{m}^{2}\right)(8)$, re-transplantation, and bilateral subcostal incision with midline extension (6), have been recognized as predisposing risk factors. Apart from the aforementioned parameters, the study published by de Goede et al., has demonstrated that advanced recipient's age ( $>60$ years) is an additional risk factor for the development of post-transplantation hernia (7).

According to Smith et al. (10), obesity is an independent risk factor for hernias. The mechanism underlying this phenomenon includes an increased intraabdominal pressure, setting the incision under mechanical stress. Moreover, obese patients are more prone to surgical site infections, a fact which favors incisional hernia development. In univariate analysis, obesity was among the most important risk factors for hernia development, while in multivariate analysis, obesity remained an important risk factor only for patients subjected to LT (10). 


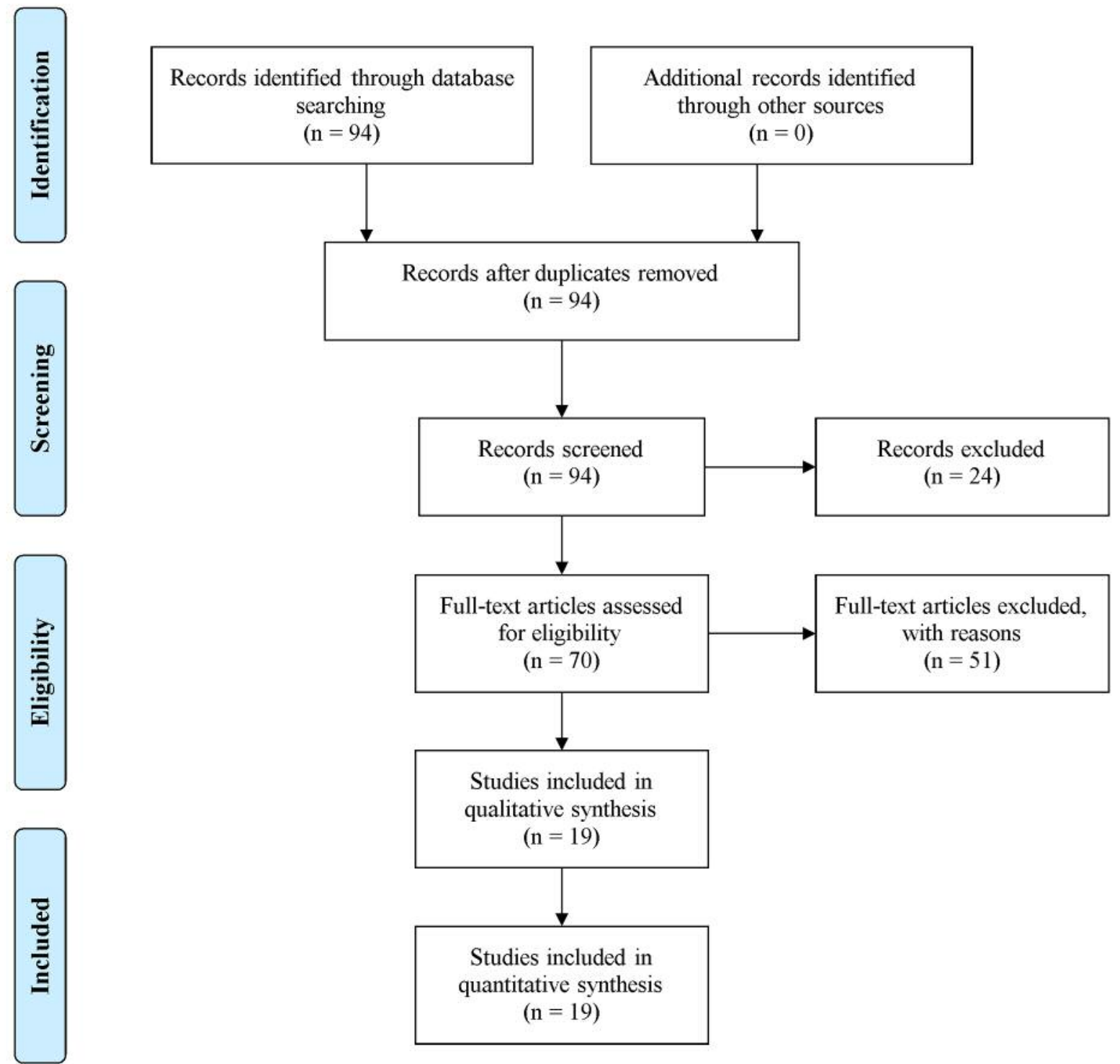

Figure 2. Prisma flow diagram for study identification and selection.

Immunosuppressive therapy seems to be an important and modifiable risk factor for the development of incisional hernia, with several studies yielding a wide variety of outcomes. The negative impact of steroids on the wound healing process has been well documented, not only in LT patients, but in all types of incisions $(6,14)$. Apart from steroids, MMF (mycophenolate mofetil) administration has been documented to be an additional risk factor for hernia formation (15). Finally, immunosuppressive therapy with the use of mTOR inhibitors, such as Sirolimus, has been associated with higher rates of incisional hernia development $(9,13,16)$.
Laparoscopic vs. open repair. Traditionally, surgical repair of incisional hernias, especially the large ones, was performed in an open fashion, either with mesh implementation in an inlay or onlay fashion, or with primary closure (Figure 3A, B, C and D). Several studies reviewing post-transplantation open incisional hernia repair have claimed that mesh implementation diminishes the risk of hernia recurrence, without amplifying the risk of infection. The same results have also been observed regarding other abdominal transplant recipients $(11,12)$.

Nowadays, the extensive use of laparoscopic techniques has dramatically altered the surgical repair options of these 
Table I. Studies included in the literature review.

\begin{tabular}{|c|c|c|c|c|c|c|c|c|}
\hline Author & $\begin{array}{l}\text { Type } \\
\text { of } \\
\text { study }\end{array}$ & $\begin{array}{c}\text { Number } \\
\text { of liver } \\
\text { transplantation } \\
\text { patients }\end{array}$ & $\begin{array}{l}\text { Post liver } \\
\text { transplantation } \\
\text { median } \\
\text { follow-up } \\
\text { in months } \\
\text { (Range) }\end{array}$ & $\begin{array}{c}\text { Number } \\
\text { of incisional } \\
\text { hernia } \\
\text { patients } \\
\text { (\% Cohort) }\end{array}$ & $\begin{array}{l}\text { Risk } \\
\text { factors for } \\
\text { incisional } \\
\text { hernia } \\
\text { formation }\end{array}$ & $\begin{array}{l}\text { Type } \\
\text { of } \\
\text { surgical } \\
\text { repair }\end{array}$ & $\begin{array}{l}\text { Recurrence } \\
\text { rate } \\
(\%)\end{array}$ & $\begin{array}{l}\text { Post hernia } \\
\text { repair } \\
\text { median } \\
\text { follow-up } \\
\text { in months } \\
\text { (Range) }\end{array}$ \\
\hline $\begin{array}{l}\text { Gomez } \\
\text { et al., } \\
2001 \text { (14) }\end{array}$ & Retrospective & 465 & NR & $54(11.6 \%)$ & $\begin{array}{c}\bullet \text { Age } \\
\bullet \text { Steroids } \\
\bullet \text { Male gender } \\
\cdot \text { Mesh repair }(\mathrm{n}=37)\end{array}$ & $\begin{array}{c}\text { - Primary repair } \\
\qquad(\mathrm{n}=3)\end{array}$ & $15 \%$ & 42 (NR) \\
\hline $\begin{array}{l}\text { Andreoni } \\
\text { et al., } \\
2002(24)\end{array}$ & Retrospective & NR & NR & 21 (NR) & NR & NR & $33 \%$ & NR \\
\hline $\begin{array}{l}\text { Janssen } \\
\text { et al., } \\
2002(11)\end{array}$ & Retrospective & 290 & NR & $50(17 \%)$ & $\begin{array}{c}\bullet \text { Steroids } \\
\text { - Transverse incision } \\
\text { with midline extension } \\
\text { - Post - transplantation } \\
\text { thrombocytopenia }\end{array}$ & $\begin{array}{c}\text { - Primary repair } \\
(\mathrm{n}=30) \\
\text { - Mesh repair } \\
(\mathrm{n}=14)\end{array}$ & $22 \%$ & NR \\
\hline $\begin{array}{l}\text { Piazzese } \\
\text { et al., } \\
2004 \text { (8) }\end{array}$ & Retrospective & 623 & NR (2-140) & $31(4.9 \%)$ & $\begin{array}{c}\bullet \text { Male gender } \\
\text { - Immunosuppression } \\
\bullet \text { BMI }>25 \\
\text { - Severe ascites } \\
\text { - Virus correlated } \\
\text { cirrhosis } \\
\text { - Transverse incision } \\
\text { with midline extension }\end{array}$ & $\begin{array}{c}\text { - Primary repair } \\
(\mathrm{n}=17) \\
\text { - Mesh repair } \\
(\mathrm{n}=14)\end{array}$ & $6.4 \%$ & NR \\
\hline $\begin{array}{l}\text { Vardanian } \\
\text { et al., } \\
2006(12)\end{array}$ & Retrospective & 959 & $14(2-51)$ & $44(4.6 \%)$ & $\begin{array}{l}\text { - Living donor graft } \\
\text { - Primary repair }(n=15) \\
\text { - Mesh repair }(n=29)\end{array}$ & $16 \%$ & NR & \\
\hline $\begin{array}{l}\text { Kahn } \\
\text { et al., } \\
2007 \text { (13) }\end{array}$ & Retrospective & 90 & $13(1-44)$ & $17(23.3 \%)$ & $\begin{array}{l}\text { - Cirrhosis (End stage) } \\
\text { - Immunosuppression }\end{array}$ & $\begin{array}{c}\text { - Primary repair } \\
(\mathrm{n}=15) \\
- \text { Mesh repair } \\
(\mathrm{n}=2)\end{array}$ & $18 \%$ & $\begin{array}{l}>44 \\
(\mathrm{NR})\end{array}$ \\
\hline $\begin{array}{l}\text { Mekeel } \\
\text { et al., } \\
2007 \text { (17) }\end{array}$ & Retrospective & 365 & NR & $27(7.6 \%)$ & NR & $\begin{array}{c}\text { - Primary repair } \\
(\mathrm{n}=26) \\
\text { - Mesh Repair } \\
(\mathrm{n}=1)\end{array}$ & $18.5 \%$ & $\begin{array}{c}\mathrm{NR} \\
(1.8-79)\end{array}$ \\
\hline $\begin{array}{l}\text { Harold } \\
\text { et al., } \\
2009(25)\end{array}$ & Retrospective & NR & NR & $21(13.2 \%)$ & NR & $\begin{array}{l}\text { Mesh repair } \\
\quad(\mathrm{n}=21)\end{array}$ & $7.9 \%$ & $\begin{array}{c}\mathrm{NR} \\
(1.1-41)\end{array}$ \\
\hline $\begin{array}{l}\text { Gastaca } \\
\text { et al., } \\
2010(6)\end{array}$ & Retrospective & 626 & NR & $11(1.7 \%)$ & $\begin{array}{c}\bullet \text { Re-laparotomy } \\
\bullet \text { Steroids } \\
\bullet \text { Transverse incision } \\
\text { with midline extension }\end{array}$ & NR & NR & NR \\
\hline $\begin{array}{l}\text { Kurmann } \\
\text { et al., } \\
2010(26)\end{array}$ & Prospective & 225 & $17(5-138)$ & $57(25 \%)$ & $\begin{array}{l}\text { - Male gender } \\
\cdot \text { BMI }>25\end{array}$ & $\begin{array}{c}\text { - Open repair } \\
(\mathrm{n}=31) \\
\text { - Laparoscopic } \\
\text { repair }(\mathrm{n}=13) \\
\text { - Primary repair } \\
(\mathrm{n}=6) \\
\text { - Mesh repair } \\
(\mathrm{n}=38)\end{array}$ & $25 \%$ & $\begin{array}{c}\mathrm{NR} \\
(6-157)\end{array}$ \\
\hline $\begin{array}{l}\text { Piardi } \\
\text { et al., } \\
2010(22)\end{array}$ & Retrospective & 422 & $17.6(5-60)$ & $36(8.5 \%)$ & $\begin{array}{c}\cdot \text { Male gender } \\
\cdot \text { BMI }>25 \\
\cdot \text { Preoperative ascites } \\
\cdot \text { Preoperative } \\
\text { diabetes mellitus } \\
\cdot \text { Preoperative COPD }\end{array}$ & $\begin{array}{c}\text { - Primary repair } \\
(\mathrm{n}=5) \\
\text { - Mesh repair } \\
(\mathrm{n}=31)\end{array}$ & $11 \%$ & $\begin{array}{l}50.5 \\
(\mathrm{NR})\end{array}$ \\
\hline
\end{tabular}


Table I. Continued

\begin{tabular}{|c|c|c|c|c|c|c|c|c|}
\hline Author & $\begin{array}{l}\text { Type } \\
\text { of } \\
\text { study }\end{array}$ & $\begin{array}{c}\text { Number } \\
\text { of liver } \\
\text { transplantation } \\
\text { patients }\end{array}$ & $\begin{array}{c}\text { Post liver } \\
\text { transplantation } \\
\text { median } \\
\text { follow-up } \\
\text { in months } \\
\text { (Range) }\end{array}$ & $\begin{array}{l}\text { Number } \\
\text { of incisional } \\
\text { hernia } \\
\text { patients } \\
\text { (\% Cohort) }\end{array}$ & $\begin{array}{l}\text { Risk } \\
\text { factors for } \\
\text { incisional } \\
\text { hernia } \\
\text { formation }\end{array}$ & $\begin{array}{l}\text { Type } \\
\text { of } \\
\text { surgical } \\
\text { repair }\end{array}$ & $\begin{array}{l}\text { Recurrence } \\
\text { rate } \\
(\%)\end{array}$ & $\begin{array}{l}\text { Post hernia } \\
\text { repair } \\
\text { median } \\
\text { follow-up } \\
\text { in months } \\
\text { (Range) }\end{array}$ \\
\hline $\begin{array}{l}\text { Montalti } \\
\text { et al., } \\
2012(9)\end{array}$ & Retrospective & 373 & $47(1-107)$ & $121(32.4 \%)$ & $\begin{array}{c}\cdot \text { Male gender } \\
\cdot \text { BMI } \geq 29 \\
\cdot \text { MELD score } \geq 22 \\
\cdot \text { HBV infection } \\
\cdot \text { mTOR inhibitors }\end{array}$ & $\begin{array}{l}\text { Mesh repair } \\
\quad(n=109)\end{array}$ & $3.7 \%$ & NR \\
\hline $\begin{array}{l}\text { Fikatas } \\
\text { et al., } \\
2013(15)\end{array}$ & Prospective & 810 & $21.1(4.6-76.7)$ & $77(9.5 \%)$ & $\begin{array}{c}\cdot \text { Age }>50 \\
\cdot \text { BMI }>25 \\
\cdot \text { Re-laparotomy }\end{array}$ & NR & $15.6 \%$ & $\begin{array}{c}7.9 \\
(4.8-46.8)\end{array}$ \\
\hline $\begin{array}{l}\text { Ozgor } \\
\text { et al., } \\
2014 \text { (27) }\end{array}$ & Retrospective & 173 & $17.6(8-31)$ & $44(25.4 \%)$ & - Relaparotomy & $\begin{array}{l}\text { Mesh repair } \\
\quad(n=14)\end{array}$ & $0 \%$ & $\begin{array}{c}19.2 \\
(13-36)\end{array}$ \\
\hline $\begin{array}{l}\text { De Goede } \\
\text { et al., } \\
2014(7)\end{array}$ & Cross-sectional & 140 & 33 (NR) & $60(43 \%)$ & $\begin{array}{c}\text { - Advanced age } \\
\text { - Prolonged ICU stay } \\
\text { - Surgical site infection }\end{array}$ & $\begin{array}{l}\text { Mesh repair } \\
\quad(n=10)\end{array}$ & NR & NR \\
\hline $\begin{array}{l}\text { Weiss } \\
\text { et al., } \\
2015 \text { (16) }\end{array}$ & Retrospective & 755 & $31(7-55)$ & $54(7.15 \%)$ & $\begin{array}{l}\text { - Increased BMI } \\
\text { - Sirolimus }\end{array}$ & $\begin{array}{l}\text { Mesh repair } \\
\quad(n=54)\end{array}$ & $17 \%$ & $\begin{array}{c}90 \\
(\mathrm{NR})\end{array}$ \\
\hline $\begin{array}{l}\text { Smith } \\
\text { et al., } \\
2015 \text { (10) }\end{array}$ & Retrospective & 718 & 50 (NR) & $136(19 \%)$ & $\begin{array}{c}\bullet \text { BMI }>25 \\
\text { - Surgical site infection }\end{array}$ & NR & NR & $\begin{array}{c}120 \\
(\mathrm{NR})\end{array}$ \\
\hline $\begin{array}{l}\text { Hegab } \\
\text { et al., } \\
2016(18)\end{array}$ & Retrospective & 488 & $48.3(6.4-60.1)$ & $33(6.9 \%)$ & $\begin{array}{c}\text { - Ascites }>4 \mathrm{~L} \\
\text { - Male gender } \\
\text { - BMI>28 } \\
\text { - Age>60 years } \\
\text { - Reoperation }\end{array}$ & $\begin{array}{l}\text { Mesh repair } \\
\quad(n=25)\end{array}$ & $4 \%$ & NR \\
\hline $\begin{array}{l}\text { Lee } \\
\text { et al., } \\
2018(28)\end{array}$ & Retrospective & 1044 & NR (42-122) & $79(7.6 \%)$ & $\begin{array}{l}\text { - Age }>55 \text { years } \\
\text { - Increased BMI }\end{array}$ & NR & NR & NR \\
\hline
\end{tabular}

NR: Not reported; BMI: body mass index; ICU: intensive care unit.

patients. Even large ventral and incisional hernias in nontransplant patients are more frequently repaired laparoscopically than in the past. Laparoscopic repair of ventral hernias has demonstrated fewer recurrences as well as infections, compared with an open repair (17), and has become the procedure of choice in experienced centers. Despite the prolonged operative time, in experienced hands, laparoscopic repair has been proven to be a safe and feasible alternative for post-transplantation hernia patients, demonstrating an outcome superior to its open counterpart, in terms of shorter length of hospital stay (LOS), and lower recurrence and complication rates. Recurrence rates for transplanted patients range from 3-10\%, while infection rates lie between 1 and $3 \%(17,18)$. Surprisingly, though, a metaanalysis of 8 studies comparing open $v s$. laparoscopic repair, concluded that short-term complications were half as likely to occur (14\% vs. $27 \%$ ) after a laparoscopic repair (19).
From another aspect, large incisions together with the administered immunosuppressive therapy in transplanted patients, often result in the development of large and/or multiple incisional hernias. The study by Raftopoulos et al. has reported on 72 patients suffering from large ventral or incisional hernias with an average hernia surface area of $125 \mathrm{~cm}^{2}$ and examined the outcomes of hernia repair. Major complication rate as well as hernia recurrence rate were significantly reduced in the laparoscopic repair arm of the study (20).

Mekeel et al. have analyzed the outcomes of 27 patients who underwent incisional hernia repair following LT. Patients treated laparoscopically $(n=13)$, demonstrated a low risk of mesh contamination and hernia recurrence, however, no significant difference was observed between the open and laparoscopic repair group. It should be noted, however, that the open repair patients had undergone more abdominal operations before transplantation than their laparoscopic 

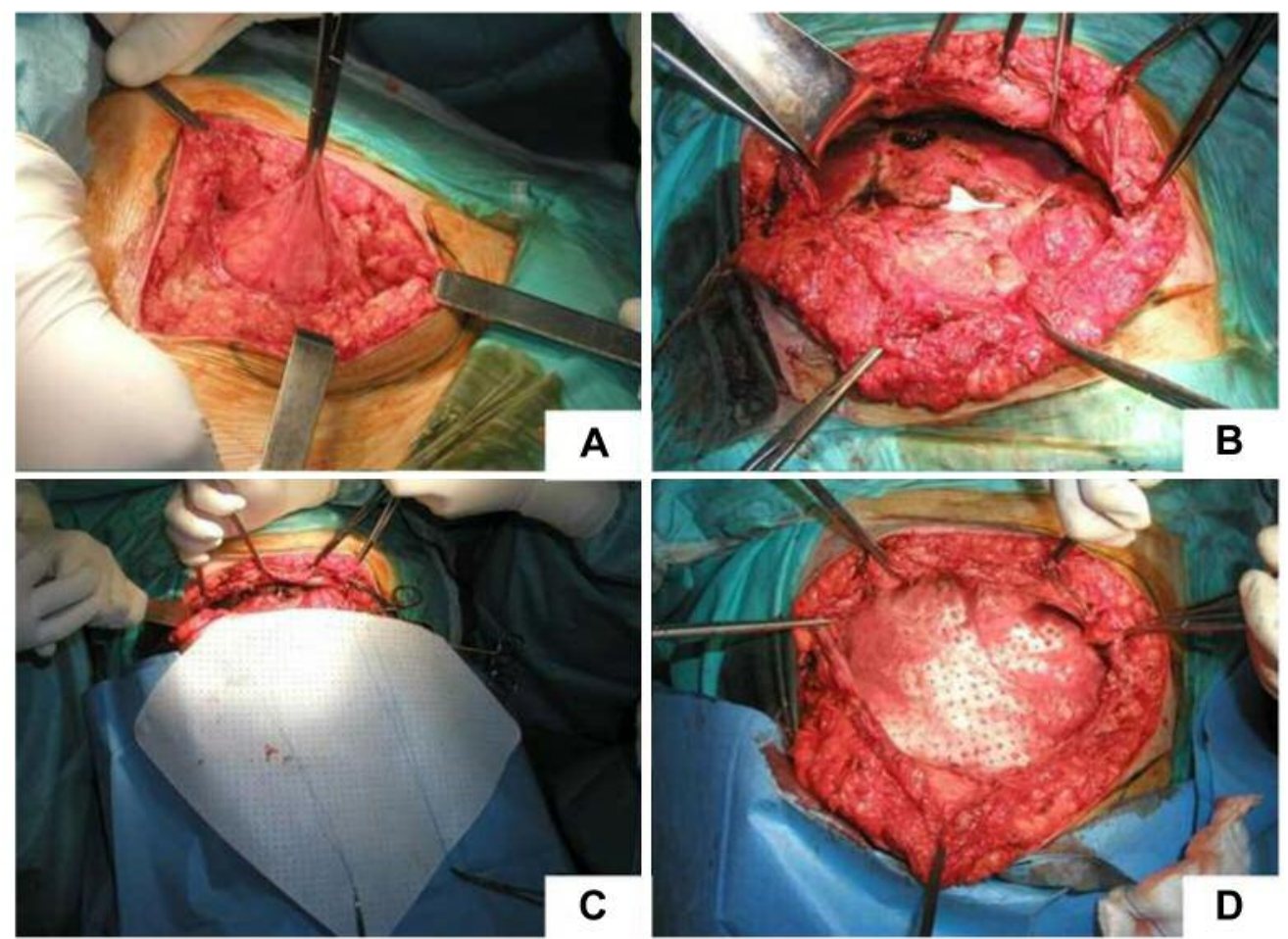

Figure 3. Intraoperative findings during open hernia repair. A: Hernia sac; B: Hernia content; C, D: Hernia repair using intraperitoneal mesh.

counterparts, which may explain the increased risk of hernia recurrence in open repair patients, due to the presence of weaker abdominal fascia. Despite this fact, the postoperative LOS in the laparoscopic group was significantly longer, compared with the open repair (17).

Nowadays, several studies have shed more light on the optimal type of surgical repair for incisional hernias, apart from post-transplantation incisions. Al Chalabi et al. have completed a meta-analysis of randomized controlled trials regarding the management of incisional hernia, and concluded that laparoscopic repair is safe and reliable, requiring a longer intra-operative time compared to open repair, without any statistically significant difference between them. The LOS between the two arms of the study was equal, as was also the recurrence rate, with a postoperative infection rate being higher in the open hernia repair group (21). In the same way, larger prospective controlled trials are required to clarify exactly the role and potential benefits of laparoscopic surgery, over an open repair, in the management of post-transplantation incisional hernias.

Technical difficulties, special considerations. Surgeons handling this patient group are confronted with some specific challenges. Technical difficulties arise mainly due to the large extent of incision, the different types of incisions, especially near the xiphoid process and costal margin, the large hernia surface and the multiple re-operations. Due to the variability in hernia cases, surgeons must be experienced in performing various types of surgical repair, with or without implementation of a mesh. Polypropylene mesh may be the first choice of surgical treatment of posttransplantation patients (22), but biological prosthesis is another useful and safe option in abdominal wall repair surgery in these patients (23).

Undoubtedly, dense intraabdominal adhesions are found in most cases. Prolonged or impaired healing, due to the immunosuppressive therapy, are expected to cause considerable morbidity (18). Surgeons must be familiar with the variety of combinations of the administered immunosuppressive agents and to consider their temporary adjustment or even discontinuation perioperatively. Moreover, liver transplantation itself, as well as its impact on body homeostasis, may strongly affect the postoperative LOS and hospital care. Treatment of a perioperative graft dysfunction or an abnormality discovered from an intraoperative biopsy of the liver graft may also be encountered $(18,24)$. Finally, vulnerability of immunosuppressed patients to various infections, not exclusively related to the prosthetic mesh, may complicate and prolong the postoperative course. 


\section{Conclusion}

The incidence of incisional hernia after LT varies among published studies. It is a fact that liver transplant patients have most of the reported risk factors predisposing to such a complication. Although the traditional approach consists of an open surgical repair with mesh implementation, some recent reports have favored the role and effectiveness of laparoscopic surgery, which has demonstrated a competitive, if not equivalent, outcome in selected cases. Moreover, the pre- and post-operative management of these cases is usually very demanding, due to conditions related either to immunosuppressive therapy or graft function. Considering all the aforementioned data, these patients should be better managed in transplant centers with appropriate experience. Finally, randomized controlled studies are needed, in order to estimate the best treatment strategy for these patients.

\section{Conflicts of Interest}

The Authors declare that there is no conflict of interest.

\section{Authors' Contributions}

NG designed the study and wrote the article. CD, MS and AG collected the data. ES, DS, DP, CD and DD offered scientific advice. DD and NIN revised the article.

\section{Acknowledgements}

Special thanks to Efstathios Antoniou for the intraoperative images.

\section{References}

1 Bucknall TE, Cox PJ and Ellis H: Burst abdomen and incisional hernia: a prospective study of 1129 major laparotomies. Br Med J (Clin Res Ed) 284: 931-933, 1982. PMID: 6279229.

2 Sanders DL and Kingsnorth AN: The modern management of incisional hernias. BMJ 344: e2843, 2012. PMID: 22573647. DOI: $10.1136 /$ bmj.e2 2843

3 Bickenbach KA, Karanicolas PJ, Ammori JB, Jayaraman S, Winter JM, Fields RC, Govindarajan A, Nir I, Rocha FG and Brennan MF: Up and down or side to side? A systematic review and meta-analysis examining the impact of incision on outcomes after abdominal surgery. Am J Surg 206: 400-409, 2013. PMID: 23570737. DOI: 10.1016/j.amjsurg.2012.11.008

4 George $\mathrm{CD}$ and Ellis $\mathrm{H}$ : The results of incisional hernia repair: a twelve year review. Ann R Coll Surg Engl 68: 185-187, 1986. PMID: 3789602.

5 Moris D, Bokos J, Vailas M, Kakavia K, Spartalis E, Athanasiou A, Schizas D and Vernadakis S: Renal paratransplant hernia revealed: a review of the literature. Hernia 21: 363-367, 2017. PMID: 27866294. DOI: 10.1007/s10029-016-1551-1

6 Gastaca M, Valdivieso A, Ruiz P and de Urbina JO: Reducing the incidence of incisional hernia after liver transplantation. Transpl Int 23: 559-560, 2010. PMID: 19906033. DOI: 10.1111/ j.1432-2277.2009.00992.x
7 de Goede B, Eker HH, Klitsie PJ, van Kempen BJ, Polak WG, Hop WC, Metselaar HJ, Tilanus HW, Lange JF and Kazemier G: Incisional hernia after liver transplantation: risk factors and health-related quality of life. Clin Transplant 28: 829-836, 2014. PMID: 24806311. DOI: $10.1111 /$ ctr.12386

8 Piazzese E, Montalti R, Beltempo P, Bertelli R, Puviani L, Pacile V, Nardo B and Cavallari A: Incidence, predisposing factors, and results of surgical treatment of incisional hernia after orthotopic liver transplantation. Transplant Proc 36: 3097-3098, 2004. PMID: 15686704, DOI: 10.1016/j.transproceed.2004.10.047

9 Montalti R, Mimmo A, Rompianesi G, Serra V, Cautero N, Ballarin R, De Ruvo N, Cunningham Gerring R, Enrico Gerunda $G$ and Di Benedetto F: Early use of mammalian target of rapamycin inhibitors is an independent risk factor for incisional hernia development after liver transplantation. Liver Transpl 18: 188-194, 2012. PMID: 21987434. DOI: $10.1002 / 1 \mathrm{t} .22445$

10 Smith CT, Katz MG, Foley D, Welch B, Leverson GE, Funk LM and Greenberg JA: Incidence and risk factors of incisional hernia formation following abdominal organ transplantation. Surg Endosc 29: 398-404, 2015. PMID: 25125093. DOI: 10.1007/ s00464-014-3682-8

11 Janssen H, Lange R, Erhard J, Malago M, Eigler FW and Broelsch CE: Causative factors, surgical treatment and outcome of incisional hernia after liver transplantation. Br J Surg 89: 1049-1054, 2002. PMID: 12153634. DOI: 10.1046/j.13652168.2002.02165.x

12 Vardanian AJ, Farmer DG, Ghobrial RM, Busuttil RW and Hiatt JR: Incisional hernia after liver transplantation. J Am Coll Surg 203: 421-425, 2006. PMID: 17000384. DOI: 10.1016/ j.jamcollsurg.2006.06.017

13 Kahn J, Muller H, Iberer F, Kniepeiss D, Duller D, Rehak P and Tscheliessnigg $\mathrm{K}$ : Incisional hernia following liver transplantation: incidence and predisposing factors. Clin Transplant 21: 423-426, 2007. PMID: 17488396. DOI: 10.1111/j.1399-0012.2007.00666.x

14 Gomez R, Hidalgo M, Marques E, Marin L, Loinaz C, Gonzalez I, Garcia I and Moreno E: Incidence and predisposing factors for incisional hernia in patients with liver transplantation. Hernia 5: 172-176, 2001. PMID: 12003043.

15 Fikatas P, Schoening W, Lee JE, Chopra SS, Seehofer D, Guckelberger O, Puhl G, Neuhaus P and Schmidt SC: Incidence, risk factors and management of incisional hernia in a high volume liver transplant center. Ann Transplant 18: 223-230, 2013. PMID: 23792524. DOI: 10.12659/AOT.883914

16 Weiss S, Weissenbacher A, Sucher R, Denecke C, Brandl A, Messner F, Oellinger R, Schneeberger S, Schmid T, Pratschke J and Biebl M: Outcome analysis of laparoscopic incisional hernia repair and risk factors for hernia recurrence in liver transplant patients. Clin Transplant 29: 866-871, 2015. PMID: 25924693. DOI: $10.1111 /$ ctr.12558

17 Mekeel K, Mulligan D, Reddy KS, Moss A and Harold K: Laparoscopic incisional hernia repair after liver transplantation. Liver Transpl 13: 1576-1581, 2007. PMID: 17969189. DOI: 10.1002/lt.21290

18 Hegab B, Abdelfattah MR, Azzam A and Al Sebayel M: The usefulness of laparoscopic hernia repair in the management of incisional hernia following liver transplantation. J Minim Access Surg 12: 58-62, 2016. PMID: 26917921. DOI: 10.4103/09729941.152102 
19 Goodney PP, Birkmeyer CM and Birkmeyer JD: Short-term outcomes of laparoscopic and open ventral hernia repair: a metaanalysis. Arch Surg 137: 1161-1165, 2002. PMID: 12361426.

20 Raftopoulos I, Vanuno D, Khorsand J, Kouraklis G and Lasky P: Comparison of open and laparoscopic prosthetic repair of large ventral hernias. JSLS 7: 227-232, 2003. PMID: 14558710.

21 Al Chalabi H, Larkin J, Mehigan B and McCormick P: A systematic review of laparoscopic versus open abdominal incisional hernia repair, with meta-analysis of randomized controlled trials. Int J Surg 20: 65-74, 2015. PMID: 26074289. DOI: $10.1016 /$ j.ijsu.2015.05.050

22 Piardi T, Audet M, Panaro F, Gheza F, Cag M, Portolani N, Cinqualbre $J$ and Wolf $P$ : Incisional hernia repair after liver transplantation: role of the mesh. Transplant Proc 42: 1244-1247, 2010. PMID: 20534272. DOI: 10.1016/j.transproceed. 2010. 03.085

23 Coccolini F, Catena F, Bertuzzo VR, Ercolani G, Pinna A and Ansaloni L: Abdominal wall defect repair with biological prosthesis in transplanted patients: single center retrospective analysis and review of the literature. Updates Surg 65: 191-196, 2013. PMID: 23636834. DOI: 10.1007/s13304-013-0212-5

24 Andreoni KA, Lightfoot H Jr, Gerber DA, Johnson MW and Fair $\mathrm{JH}$ : Laparoscopic incisional hernia repair in liver transplant and other immunosuppressed patients. Am J Transplant 2: 349-354, 2002. PMID: 12118857.
25 Harold K, Mekeel K, Spitler J, Frisella M, Merritt M, Tessier D and Matthews B: Outcomes analysis of laparoscopic ventral hernia repair in transplant patients. Surg Endosc 23: 1835-1838, 2009. PMID: 19118430. DOI: 10.1007/s00464-008-0273-6

26 Kurmann A, Beldi G, Vorburger SA, Seiler CA and Candinas D: Laparoscopic incisional hernia repair is feasible and safe after liver transplantation. Surg Endosc 24: 1451-1455, 2010. PMID: 20039072. DOI: 10.1007/s00464-009-0799-2

27 Ozgor D, Dirican A, Ates M, Yilmaz M, Isik B and Yilmaz S: Incisional hernia in recipients of adult to adult living donor liver transplantation. World J Surg 38: 2122-2125, 2014. PMID: 24705805. DOI: 10.1007/s00268-014-2528-9

28 Lee JS, Kim JM, Kim KS, Choi GS, Joh JW and Lee SK: Predictors of incisional hernia in adult liver transplant recipients. Hernia 23: 61-65, 2019. PMID: 30406851. DOI: 10.1007/ s10029-018-1845-6

Received April 29, 2019

Revised June 5, 2019

Accepted June 6, 2019 